Tér és Társadalom 18. évf. 2004/2. 37-50. p.

\title{
AUTÓPÁLYÁK ÉS A VÁROSI FEJLŐDÉS
}

\author{
(The Highways and Urban Development)
}

\section{TÓTH GÉZA}

Kulcsszavak:

autópálya térszerkezet szuburbanizáció peremváros közlekedésifolyosók logisztika

Az autópályák és a városok szerkezete közötti kapcsolat több összefuggésben is vizsgálható. Tanulmányozhatók egyrészt azok a városok, amelyek alapszerkezetét a közúti közlekedés folyamatai határozták meg, másrészt pedig az utóbbi évtizedek szuburbanizációs folyamatai, melyek a regionális különbségek mellett az egész világon jellemzöek. A szuburbanizációnak több kâros hatása van, melyeket sokan az autópályák létével kapcsolnak össze. Vannak olyan elképzelések, amelyek segitségével e hatások mérsékelhetők. Cikkünk e kérdésekröl igyekszik rövid áttekintést nyújtani.

\section{Városszerkezet és autópályák}

$\mathrm{Az}$ amerikai és az európai városok kialakulásukat tekintve nagyon különbözőek. Az Amerikai Egyesült Államokban a városok mai szerkezete, a városok viszonylagos fiatalsága miatt köthető valamely közlekedési mód hatásához. Itt találhatunk olyan városokat, melyek kiépülésében döntö szerepe volt a kikötöknek és a vasúti közlekedésnek (pl. Detroit, Chichago). Az USA-ban emellett elkülöníthetünk olyan városokat is, melyek szerkezetét döntően a vasút határozta meg (pl. Oklahoma City, Denver, Salt Lake City). E városokkal szembeállíthatók azon városok, amelyek térszerkezetét döntően az autópályák határozták meg (pl. Dallas, Houston, Phoenix).

A nyugat-európai városok ettỏl sokban különböznek. Lévén, hogy sokkal régebbiek, sokuknak a középkorban kiépített városközpontja van. A közlekedés és ezen belül az autópályák hatása is máshogyan érintette öket, különbözö okokra visszavezethetően. A városközpontok szerepe egészen más, mint Észak-Amerikában, itt jóval nagyobb a lakófunkció jelentősége, így a térfolyamatok is másképpen érintették őket. Mindenesetre szerkezetük módosulásában nagy szerepet játszottak az autópályák (1. ábra).

Az autópályák és a városi fejlődés közötti kapcsolatról szóló vita hosszú ideig két dologra koncentrálódott: a központi városrészek csökkenésére, illetve a szuburbanizáció erösödésére. A probléma gyökere, hogy az ipari üzemek térbeli koncentrálódása egyben telepúlési, városi koncentrációval is jár, illetve befolyásolja az adott városok térbeli folyamatait. A gazdaság folyamatait követik a társadalom területi elhelyezkedésének változásai. A központi városrészekben gyakran nagyobbak az egy före jutó kiadások, illetve magasabb az adóteher, mint a külsö telepuiléseken, $s$ ezzel megindul az elvándorlás első hulláma. E folyamatok súlyosbodtak, amikor a legfelsỏbb rétegek, illetve a legtöbb adót termelö vállalatok elmenekültek a szuburbiákba (Boarnet-Haughwout 2000). 


\author{
1. ÁBRA \\ A közutak és a térszerkezet kapcsolata \\ (The Connection between Roads and Urban Spatial Structure)
}

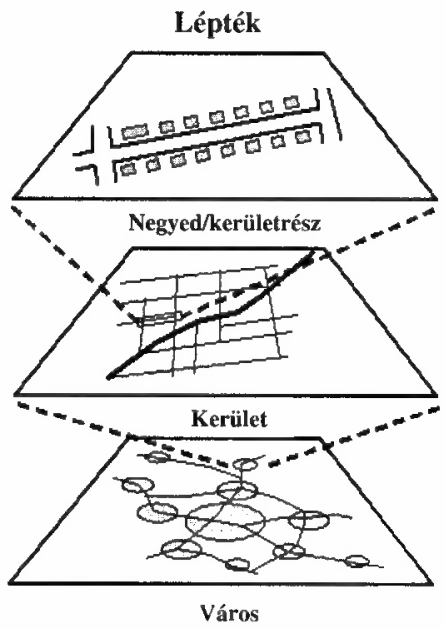

A térszerkezet összetevői

•Utcák

-Alapszolgáltatások

•Lakások

-Főutak

-Foglalkoztatási

térségek

-Autópályák

-Fô szállítási

terminálok (kikötők, repterek)

Forrás: Rodrigue 1998.

Az Amerikai Egyesült Államokban kimutatták, hogy erős a kapcsolat a város beépítettsége és a személygépkocsi-használat között. Több városban jobban nött a beépítettség, mint a népesség. Az utazás viszonylag olcsóvá vált a telekárakhoz képest, ami arra késztette a népességet, hogy olcsóbb városi perifériákon vásároljon telket. Hasonló folyamatok játszódtak le Európában is, igaz, itt a változás dinamikája alacsonyabb volt (Rodrigue 1998).

A vita arról szól, hogy többek szerint a túlburjánzó szuburbán fejlődés nagyon költséges (közmüvek, intézmények stb.), s elpazarolja a kihasználatlan központi városrészek területét, illetve infrastruktúráját, valamint jelentös zsúfoltságot és légszennyezést okoz. Mások szerint viszont a szuburbán fejlödést elsősorban azok preferálják, akik jobban szeretik a nagyvárosok peremén való életet, ahol kisebb a népsủrüség.

Kelet-Közép-Európa nagyvárosaiban a népesség mozgása sok tekintetben más, mint a korábbi amerikai, illetve nyugat-európai folyamatok. E nagyvárosokban ugyanis nemcsak a legfelsöbb rétegek költöznek a szuburbiákba, hanem - mint Prága példáján is látható - a kiköltözök két csoportra oszthatók. Az első csoportba sorolhatók az átalakulás nyertesei, az újgazdagok, akik számára az autópálya elhelyezkedése igen fontos, így lakóhelyük megválasztásánál ezt figyelembe veszik. A másik csoport viszont egyértelmủen a rendszerváltás vesztesei közé tartozik, alacsony keresetủ, alacsony képzettségủ rétegek, melyek lakóhelyválasztását csak a 
költségcsökkentés motiválja. Ebböl kifolyólag lakóhelyük területi elhelyezkedése az agglomerációkban kevésbé koncentrált, illetve egyáltalán nem függ a közlekedési infrastruktúrától (Sỳkora 1999).

Felmerülhet a kérdés, hogy az autópályák hozzájárulnak-e a decentralizációhoz, vagy eleve a növekedést generálják, ami miatt növekszik a decentralizáció? (Tyúk tojás probléma.) Van olyan vélemény is, miszerint a közúti közlekedési sebesség 20\%-os növekedésének hatása a népesség decentralizációjára (szuburbanizációjára) nagyon kicsi, amennyiben összehasonlítjuk a népesség területi elhelyezkedésének autonóm folyamataival. Jóval nagyobb hatással van viszont a foglalkoztatás területi elhelyezkedésére (Webster-Bly-Paulley 1988).

A tevékenységek decentralizációja két hatásban nyilvánult meg. Az egyik az, hogy az ingázás, melynek nagy része már a szuburbiákon belül zajlik, időtartamában nagyjából hasonló maradt. Világszerte az emberek kb. 1,2 órát utaznak naponta munkahelyuakre, az utazási módtól függetlenül. A második pedig az, hogy az utazások egyre hosszabbak, és az emberek leginkább személygépkocsival közlekednek, mind a fejlödö, mind pedig a fejlett országokban.

Az agglomerálódási folyamatban az összefüggő településtest magához kapcsolja a hozzá közel eső telepuléseket. Az agglomerálódás folyamatai a térben gyakran erösen koncentráltan, csápszerủen, vagyis a fö közlekedési vonalak mentén bontakoznak ki. Ez területi aránytalanságokat hozhat magával az agglomerálódás által érintett térségben: intenzíven/intenzívebben összefonódó térségek váltakoznak majd árnyékterületekkel, melyekben az agglomerálódás szignifikáns jegyei kevéssé figyelhetők meg (Köszegfalvi 1997).

A közgazdászok úgy vélik, hogy az autópálya-fejlesztések hatnak a városi térségek növekedésére, megváltoztatva mind a városok közötti, mind a városokon belüli elérhetőségi viszonyokat. Valamennyi ilyen elemzés a „monocentrikus” városszerkezetböl indul ki (Alonso 1964). E modellekben a munkahelyek elsősorban a városközpontokban koncentrálódnak, s e körül találhatjuk meg a lakóhelyeket. E központi terulettöl való távolsággal változik a földterület értéke is a közlekedési, illetve a kommunikációs költségekkel összefüggésben. Azok az újonnan épített autópályák, amelyek összekötötték a city-t a lakóterületekkel, csökkentik a kommunikációs költségeket. Tehát az addig alacsonyabb értékủ földterületek felértékelödnek, s csökken a city elönye, melyet az elérhetöség tekintetében élvezett. A városi térség földrajzilag is kiterjed, mivel az ingázók a munkahelyüktöl távolabb is élhetnek anélkül, hogy utazási költségeik növekednének. Így a city körüli lakóterületeken csökkeni fog a népsürüség. Összességében a monocentrikus modellekben a közlekedési infrastruktúra fejlesztése összefüggésben van a városi területek népességének decentralizációjával ( F ujita 1989).

Ezzel az elmélettel az a legfőbb gond, hogy a legtöbb nagyvárosi terület nem egyközpontú, hanem többközpontú. Emiatt dolgozták ki a policentrikus városmodellt, melyben háromféle központot különböztetünk meg, s a központok közötti teret a háztartások lakásai töltik ki, elöbb többszintes házak, majd az üzleti negyedtől 
távolodva sorházak és családi házak találhatók. E központok a következők (StutzDe Souza 1998):

1) A városközpont elkülönül, itt található az üzleti negyed, illetve a hivatalok többsége.

2) Feldolgozóipari központok, melyek a városközpontoktól távolodva általában közlekedési csomópontban találhatók. E területeken nagy az agglomerációs gazdaságok jelentősége: a kiemelkedő integrátorvállalatok magukhoz vonzzák a beszállítóikat, s egymáshoz igen közel, sőt sok esetben közös ipari parkokba települnek.

3) Kereskedelmi/logisztikai központok, melyek a külső csomópontokban alakulnak ki. Ezek az alközpontok már nemcsak a városban müködö, de a környező településeken lévö cégeket, háztartásokat is kiszolgálják.

Az autópályák és az elkerülő utak elösegítették a szuburbiák és az alközpontok fejlődését, mely területek versenyeznek a központi üzleti negyeddel a gazdasági tevékenységek vonzásában. Így nagyon sok új munkahely a szuburbiákba került (vagy sok esetben azon kívül, teljesen új telephelyre), s a városok tevékenységi rendszere módosult. A városok különböző részeinek különböző a dinamizmusa.

A városi térszerkezet módosulása tekintetében ez utóbbi, nagy forgalmú csomópontokba telepített logisztikai központok jelentik az egyik fontos mozgatórugót. $\mathrm{E}$ központok elsösorban azért települnek az autópályák közelébe, mert így tudnak a fogyasztókhoz a legközelebb kerülni, s termékeiket a piac igényeinek megfelelően azonnal, irányítottan tudják szállítani. Érdemes azt is megfigyelni, hogy még olyan cégek is igyekeznek az autópályák mentén települni, amelyek csak belföldi szolgáltatást látnak el (Berion 2000). Vagy a logisztikai központokhoz kapcsolódva (Tóth 2000), vagy azoktól elkülönülten, az autópálya-felhajtótól igen kis távolságra hozzák létre a város új ipari parkjait, melyek a helyi gazdasági környezet új, helyi alközpontjaivá válnak. Az ilyen alközpontokhoz igazodva a térbeli anyag-, energia-, illetve munkaeró-áramlás átalakul, s bỏvül a város közvetlen vonzáskörzete. $\mathrm{Az}$ is bizonyítja az autópályák szerepét e folyamatban, hogy az ipari parkok legdinamikusabb fejlödése térben meglehetősen koncentrált képet mutat, s a legközelebbi felhajtótól csupán nẻhány percre fekvők elörehaladása jóval nagyobb, mint a felhajtótól távolabb lévőké (Berion 2000).

E központokban a nagy bevásárlóközpontok, illetve a közraktárak megtelepülése is különösen jellemző, ami minden nagyváros körül tendencia. Közép-Európa nagyvárosai, elsősorban fỏvárosai környékén viszont e változás meglehetősen gyorsan és radikálisan ment végbe. Prágában például a kereskedelmi forgalom majd fele a kilencvenes évek elején még a városközpontban valósult meg, míg néhány év alatt a forgalom jelentős része az agglomerációba került át (Sỳkora 1999).

A szuburbán térségek továbbfejlödését jelentheti az autópályák mentén a városi térségek kinyúlása, meghosszabbodása, mely térségeket nevezhetünk peri-urbán térségeknek. Ezek ugyanis jóval a városi magterületeken és a szuburbiákon kívül helyezkednek el, de még mindig elfogadható közlekedési távolságon belül. Ilyen 
fejlődés jelenleg elsösorban az Egyesült Államok legnagyobb városainak környékén figyelhetö meg.

További fontos jelenség az ún. peremvárosok (edge city) megjelenése. A folyamatot, mely a szuburbanizáció harmadik hullámának tekinthetö, Joel Garreau (1991) írta le. Véleménye szerint az elsỏ hullámot a népesség kitelepülése jelentette a városközpontokból a II. világháború után. A második hullám az 1960-as, 70-es években zajlott le, amikor a szuburbiákban egyre több üzlet, bevásárlóközpont jelent meg. A harmadik hullám lényegében napjainkban is játszódik, melyet elsősorban a munkahelyek áttelepülése jellemez a szuburbiákba, aminek következtében kialakulnak a peremvárosok. Ezek a városok jelentősen különböznek a hazai szakirodalomban bolygóvárosként aposztrofált típustól.

Garreau a peremvárost öt jellemzővel definiálta:

1) A városban mintegy $500000 \mathrm{~m}^{2}$ irodai terület legyen (ez nagyjából egy jelentős belvárosban található mértékkel egyenértékủ).

2) Több mint $50000 \mathrm{~m}^{2}$ raktárterület legyen (mely egy nagy, regionális raktárnegyednek felel meg).

3) A népességet a napi ingázás jellemezze (több álláshely található itt, mint otthon).

4) A várost utazási végcélnak lehessen tekinteni (rendelkezésre állnak a szórakozási, bevásárlási, rekreációs stb. lehetöségek).

5) E település csak maximum 30 éve lehet város.

A peremvárosok tehát a szuburbiákon belül kialakuló helyi alközpontok, melyek szorosan kötődnek az autópályák létéhez, illetve több autópálya találkozási pontjaihoz, csomópontjaihoz.

A legtipikusabb peremváros Tysons Center Virginiában. A város több autópálya közelében fekszik. Néhány évtizeddel ezelött Tysons Center nem volt nagyobb, mint egy falu, ma viszont itt van a keleti part legnagyobb kereskedelmi központja, több mint 3400 szállodai szoba, több mint 100000 álláshely, illetve több mint kétmillió négyzetméter irodai helyiség. Ennek ellenére Tysons Centernek még nincs saját önkormányzata.

A folyamat következő fázisát jelenti bizonyos üzleti tevékenységek megjelenése a peremvárosok köruil (edgeless city). E térségek alacsony beépítettségủek, s szerkezetileg meglehetősen amorfak. Az épületek egymástól elszigetelt csoportokban épülnek, megközelítésük sem gyalogosan, sem tömegközlekedési eszközzel nem könnyű. Itt ugyanis a személygépkocsik használata a domináns. E területek elsősorban az olcsó földterületek miatt vonzóak a high-tech cégek, irodák, elosztóközpontok, illetve kereskedelmi vállalkozások számára (Hartshorn 2003).

Bár Közép-Európában a szuburbanizáció folyamatait még nem jellemzik a fentebb bemutatott jelenségek, mégis van arra példa, hogy a várostervezők igyekeznek ehhez nagyon hasonló módszereket alkalmazni a városközpontok tehermentesítése, illetve revitalizációja érdekében. Ilyen folyamatok játszódtak le Szlovéniában, 
Ljubljana északkeleti szélén. Nove Poljane településen ugyanis a korábbi raktártelepek átépítésével alakítottak ki egy üzleti központot, az úgynevezett „BTC City”-t. A központ $252000 \mathrm{~m}^{2}$ beépített területtel és 4000 foglalkoztatottal a fövárosi régió legnagyobb üzleti és kereskedelmi központja. A kivitelezés PPP rendszerben történt, s mára versenyképességében a városközponttal vetélkedik (Dimitrovska 2002).

\section{Konurbációk}

Az urbanizációval és a közlekedési folyosókkal (korridorokkal) kapcsolatos legújabb paradigmák a nagyobb városhalmazokkal (konurbációkkal) kapcsolatos folyamatokat jellemzik (Rodrigue 2003). E megállapítások, bár más közlekedési módok esetén is relevánsak, de leginkább mégis a közúti közlekedés, $\mathrm{s}$ ezen belül is az autópályák vonatkozásában meghatározóak (2. ábra).

\section{2. ÁBRA}

A közlekedési korridorokkal kapcsolatos paradigmák

(Paradigms of Transport Corridors)

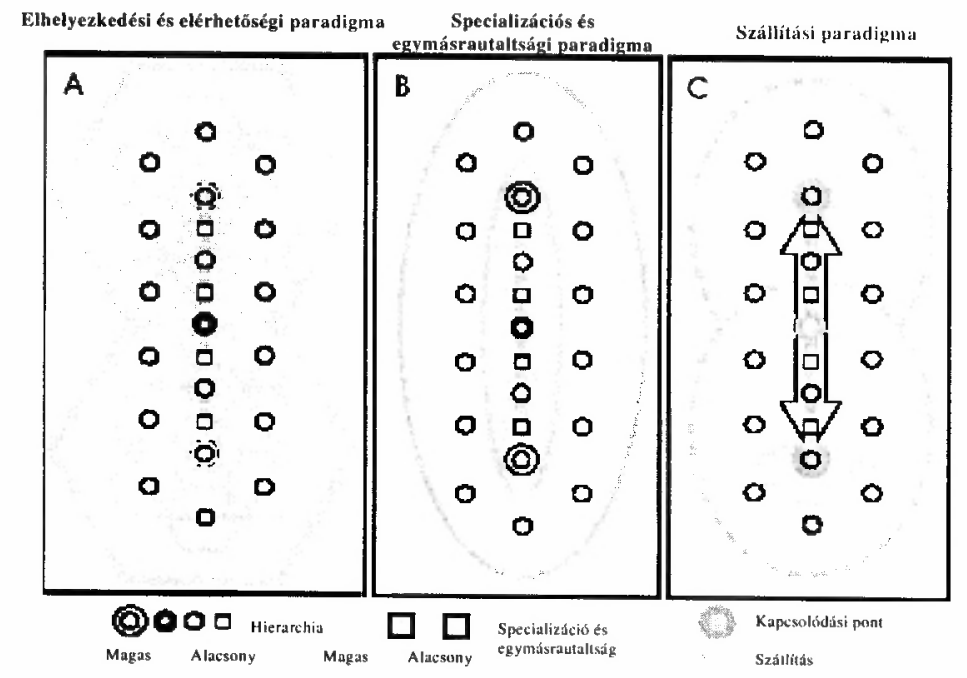

Forrás: Rodrigue 2003.

1) Az elhelyezkedési és elérhetöségi paradigma szerint a városi térséget tekinthetjük a szolgáltatások, illetve a funkciók bizonyos fokú hierarchiájának, $\mathrm{s}$ a közlekedési folyosó lényegében e hierarchián belül az interakciókat meghatározó struktúra. A szállitási költségeket meghatározónak tekintik a területi struktúra elrendezödésében, mivel valamennyi központ hátországának 
mérete attól függ, hogy rajta keresztül a vásárlók mennyi áruhoz, illetve szolgáltatáshoz tudnak hozzájutni. Az autópálya mentén viszonylag kis területen kedvezöbb az elérhetöség, míg az itt kínált áruk, illetve szolgáltatások mértéke jóval szélesebb.

2) A specializációs és egymásrautaltsági paradigma úgy tartja, hogy bizonyos városok számára a közlekedési elérhetőség nemcsak több, mint a piachoz való hozzáférés egy tényezője, hanem ezenkívül a regionális specializáció és a komparatív elónyök tekintetében is nagyon fontos. Az elérhetőség javulása mind a termelés, mind a fogyasztás területén javítja a városi térség gazdasági specializációját regionális szinten, valamint növeli a térség kölcsönös egymásrautaltságát.

3) A legfrissebb az úgynevezett szállítási paradigma. Ebben a nagyvárosi közlekedési folyosóknak három elemét különböztetjük meg.

- Kapcsolódási pontok, ahol az áruelosztás szabályozása terminálokban és szállítási központokban történik. E pontok határfelületet képeznek a globális és a regionális áruáramlások között.

- Áruszällítási korridorok, melyek lényegében egyes kapcsolódási pontok között lévő közlekedési infrastruktúrák (ez esetben autópályák).

- Áruszállitás, áruelosztás.

Funkcionálisan a kapcsolódási pontok az ellátási láncok széles skáláján belül földrajzilag koncentrált csomópontok. Több áruszállítási terminál koncentrációját jelentik, melyek mind különböző áruszállítási rendszert szolgálnak ki. Megjelenik itt az áruk átrakása egyik szállítási módról a másikra, az áruk összegyuujtése, illetve azok közvetítése más kapcsolódási pont felé.

A korridorokat vizsgálva a legfejlettebb infrastruktúrával rendelkezö államokban mindinkább megjelenik az egyes szállítási ágazatok közötti verseny, hiszen valamennyi szállítási módhoz kötődő infrastruktúra kiépítettsége magas szintủ. Így ezekben az országokban a konkrét szállítás jellege, költsége, illetve más paraméterei határozzák meg az alkalmazott szállítási módot. Ezt hazánkban az infrastruktúra fejletlensége miatt kevésbé lehet megvalósítani, viszont megjegyzendö, hogy a városi térségek fejlödésében még a legfejlettebb államokban is a közúti szállításnak van a legkiemelkedőbb szerepe, s ezen belül leginkább az autópályáknak.

Korábban az áruterminálok leginkább a központi területek közelében települtek a piac közelsége miatt. Ez némileg megváltozott, mivel a korridor jelentősen bỏvíti az áruelosztás által érintett térséget, $s$ a terminálok így már jóval nagyobb térséget tudnak kiszolgálni a korridor mentén. Így a szuburbiákban elhelyezkedö terminálok és áruelosztó központok már szerepet játszanak mind a nagyváros, mind az azt körülvevő városi térségre vonatkozó áruáramlási folyamatokban is, ami tovább erősíti az egész nagyvárosi térség fejlődését. 


\section{Közlekedés és gazdasági összefüggések}

A közlekedés kihat a gazdasági rendszerekre, s a gazdaság (tágabban, lényegében a területhasználat) is meghatározza a közlekedési rendszereket. Más szóval a közlekedés keresleti (a gazdaság igényei) és kínálati (rendelkezésre álló közlekedési hálózat) oldala kölcsönösen egymástól függoö. Például egy autópálya-csomópont építése elősegíti a kereskedelmi és szolgáltatási tevékenységek koncentrálódását, ami további közlekedési keresletet fog generálni, melynek következtében új gazdasági tevékenységek jelennek meg, s hosszú távon a regionális térszerkezet megváltozik.

Fontos arra is figyelmet fordítani, hogy az egyes cégek hogyan választják meg nagyvárosi telephelyeiket, s döntéseiket hogyan és mennyiben befolyásolja a közlekedési hozzáférés.

A kutatások egyik legáltalánosabb megállapítása, hogy a vállalkozások tömörülése a városokon belül, illetve körül elsősorban a szállítási, közlekedési előny megszerzése érdekében alakult ki. Az „agglomerációs gazdaságok” kialakulása (Nijkamp 1986; Erdösi 2000; Rodrigue 2003 stb.) arra készteti a cégeket, hogy hatékonyságuk növelése érdekében minél közelebb települjenek egymáshoz (urbanization economies). Így azok a vállalkozások, amelyek a regionális vagy a nemzeti piacokra termelnek elsősorban, a városok közötti közlekedési hálózatok csatlakozási pontjaihoz közel tömörülnek. Emellett a cégek akkor is tömörülhetnek, ha egymás számára termelnek, különösen a just-in-time elvủ beszállítás szerepének megnövekedésével (localization economies).

$\mathrm{Az}$ agglomerációs gazdaságok további lehetősége akkor áll fenn, ha a méretgazdaság (economies of scale) szerepe erősödik, vagyis a vállalatok törekszenek gazdaságosságuk növelése érdekében az üzemnagyság bizonyos nagyságrend felett tartására. Vagyis a vállalatok belső szerkezetváltással, illetve fúzióval igyekszenek méretüket növelni, amivel a közlekedési infrastruktúra termelést szétszóró hatása elleni folyamatot indítanak el.

Az agglomerációk termelékenységi előnyeirỏl szóló irodalom bemutatja, hogy a termelöerök területi koncentrációja nagyobb termelékenységet eredményez, s a terület tulajdonosai számára magasabb bevételeket. Bármely vállalkozás számára egy sürủn betelepült agglomerációba való betelepülés vélhetően csökkenti a szállítási és kommunikációs költségeket, és a fejlettebb elérhetőségi viszonyok csökkentik a központi területek, telephelyek értékét, mivel a munkaerő és a nyersanyag nagyobb távolságról is beszállítható. Hasonló megállapítást tett a lakások áraira a city és a lakóövezetek vonatkozásában Haughwout (1999).

Korábbi, az 1950-es, 60-as években készült elemzések kimutatták, hogy a fontosabb autópálya-beruházások közelében jelentősen növekedtek a telekárak. Az 1970-es, 80-as évek statisztikai vizsgálatai szerint viszont a kapcsolat gyenge és nem szignifikáns. A különbség oka elsősorban az, hogy az elsó autópályák az elérhetőségben hatalmas fejlődést jelentettek, és így a projekt közelében is nagy növekedés tapasztalható. Minél több autópályát építenek, a hálózat annál érettebbnek tekinthető, s így 
az elöbb említett növekvő hatás az új projektektől kevésbé várható, s a kisebb változás oka az elérési előny csökkenésében keresendő.

$\mathrm{Az}$ Egyesült Államokban végzett vizsgálatok emellett erós kapcsolatot látnak a városi népesség, illetve a foglalkoztatottság növekedése és az autópályák építése között. Továbbá pozitív kapcsolat figyelhető meg az autópálya-kiadások és a foglalkoztatás alakulása között azon megyékben, amelyek regionális foglalkoztatási központokként funkcionálnak, és negatív azokban, ahol nincsenek ilyen területek. Így tehát bizonyos területek nyerhetnek az útfejlesztésböl, míg mások veszthetnek.

Az autópályával rendelkező térségekben ott nagyobb a gazdasági növekedés, ahol a térség közel fekszik egy nagyvároshoz, vagy olyan településekhez, amelyeket korábban valamilyen mértékü városias fejlödés jellemzett. Azok a területek, amelyek rendelkeznek ugyan autópályával, de vidékies jellegűek, illetve távol fekszenek egy nagyvárosi agglomerációtól, kevesebb előnyt élveznek az autópálya létéböl (Raphann-Isserman 1994).

\section{A szuburbanizáció túlburjánzásának problémái}

A szuburbanizáció korábban bemutatott gazdasági elönyei mellett helytelen területfejlesztési gyakorlat esetén olyan káros hatásokat is generálhat, amelyeknek hosszú távon gazdasági, társadalmi és környezeti kárai is lehetnek. A szuburbiák egyre inkább szétterülnek olyan mértékben, amely a városi téren belül csökkenti az elérhetőséget, s ennek következtében a közlekedési (szállítási) költségek megnőnek. A lakó- és egyéb területek kiszolgálása érdekében egyre több útra és parkolóra lesz szükség, ami csökkenti a felhasználható földterület nagyságát. A növekvő távolságok miatt nőnek a közszolgáltatások biztosításának költségei is. Hosszú távon akár a gazdaság agglomerációs elönyeinek csökkenéséről is beszélhetünk, s így a regionális gazdasági tevékenység csökken.

A szuburbiákban bizonyos rétegek számára romlanak az elérhetőségi viszonyok, mely növeli a szegregációt. A nagyfokú beépítettség következtében a korábbiakkal ellentétben romlanak a lakáskörülmények, s egyre inkább csökkennek a társadalmi és személyes interakciók. A szállítási költségek növekedése társadalmi vetületének tekinthető a baleseti kockázat növekedése is.

A legáltalánosabban megjelenő problémák környezeti vonatkozásúak. A közlekedési rendszerek kiépítésével nő az áthatolhatatlan tér nagysága. Csökkennek a zöldfelületek, s így nagyfokú lesz a tér esztétikai degradációja. A növekvő energiafelhasználás mellett nö a levegö-, illetve zajszennyezés. A városi höszigetek számának növekedése szintén kedvezötlen folyamatként aposztrofálható (Litman 2003).

\section{A negatív hatások ellensúlyozásának lehetöségei}

Mint korábban már jeleztük, a közlekedés és a területhasználat között szoros a kapcsolat. Az emberek közlekedési szokásai tekintetében három dolog a meghatározó: az elérni kívánt célterületek elhelyezkedése; a szükségletek, illetve vágyak; 
valamint az általános közlekedési költségek. Mint a 3. ábra is mutatja, valamennyi tényező kihat a másikra. A három kategória bármelyikében bekövetkezö változás hatással van a másik kettőre, s így a közlekedésre.

\section{3. ÁBRA}

A közlekedési szokásokat meghatározó tényezök

(Factors Determining Travel Patterns)

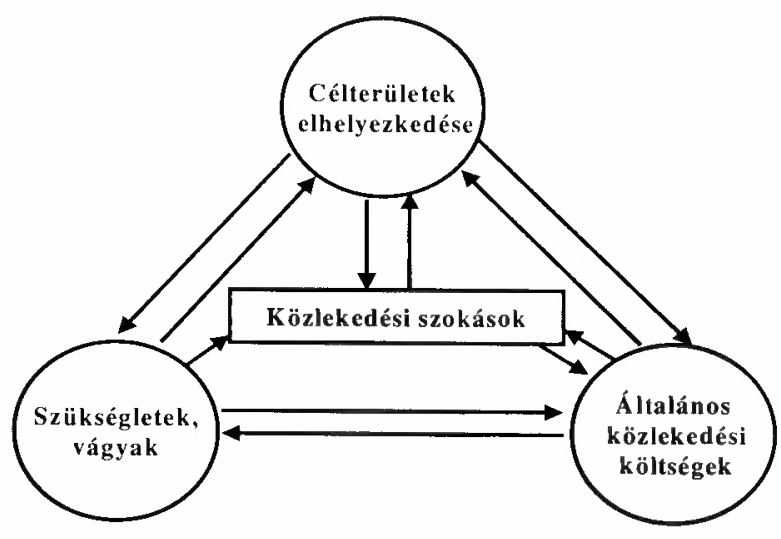

Forrás: Wee 2002.

A városi közlekedési problémák leküzdéséhez ezért e három tényezö vonatkozásában kell megoldást találni. A városfejlesztés számára a közúti közlekedés csökkentésére több módszer is elképzelhetö, ezek közül kiemelhető a potenciális célterületek koncentrálása, a változatos területhasználat, illetve a tömegközlekedési csomópontokhoz való távolság figyelembevétele a tervezésben.

Ahhoz, hogy az emberek minél ritkábban használják az autójukat, szükség van arra, hogy szükebb lakókörnyezetükben valamennyi potenciális cél (munkahely, intézmények stb.) kis távolságon belül elérhetó legyen. Így egyre gyakrabban gyalogosan, esetleg tömegközlekedést használva érik el céljaikat. A potenciális célok koncentrálása természetesen időmegtakarítást jelent, melyet az emberek más, távolabbi célok elérésére használhatnak. lgy természetesen újra használhatják gépkocsijaikat, viszont összességében az utazás mennyisége csökken.

Lényegében az elöző összefüggéshez kapcsolódik, hogy a potenciális célok megfeleló változatosságban helyezkedjenek el a városon belül. Ha kis távolságokon belül valamennyi cél elérhetó, abban az esetben nem érdemes az autót használni (Uizemanyag, parkolási díj megtakarítása). Arra van szưkség tehát, hogy minél több potenciális cél elérhetö legyen a városok alközpontjaiban, s így ne kelljen értük a központot felkeresni.

A tömegközlekedést lehetöségek szerint vonzóvá kell tenni az autóhasználattal szemben. Ebben a vonatkozásban igen fontos az idötényezö. Például az útidőhöz 
vasúti közlekedés esetén hozzá kell számolni az állomásra való eljutást, illetve onnan a célterületre való eljutást is. Vagyis akkor lehet igazán vonzó a tömegközlekedés az utasok bizonyos része számára, ha az útidőn kívüli idő számukra minél kisebb. Ehhez a potenciális célok nagyfokú koncentrációjára van szükség a vasútállomások környékén (Wee 2002).

A negatív hatások közül ezután arra igyekszünk koncentrálni, hogyan lehetséges csökkenteni az áruszállítás volumenét, ellensúlyozva az autópálya által generált forgalmat.

Az áruszállítás volumenére komoly hatással vannak a világgazdaságban egyre erősödő kereskedelmi áruáramlások, melyeket erősítenek a WTO-hoz hasonló globális kereskedelmi megállapodások, a kereskedelmi liberalizáció, illetve új, gyorsabb, költségcsökkentő eljárások. A szolgáltatási szektor jelentősége megnỏ, a vállalkozások elsősorban a fötevékenységre koncentrálnak, $\mathrm{s}$ az ehhez szorosan nem kapcsolódó egyéb tevékenységet kihelyezik (outsourcing), továbbá nagy a jelentősége a just-in-time elvű beszálításnak is (Tóth 2001). Világbanki felmérések szerint a just-in-time szálítások az USA-ban és az EK-ban 1990-ben az összes szállítás 28\%-át képezték, s 1995-96-ra elérték a 40\%-ot (Pálfalvi 2000). Mindezek mellett hangsúlyozható, hogy a regionális, illetve a helyi sajátosságoknak kiemelt jelentỏsége van a komparatív elönyök megszerzése tekintetében.

A vállalkozásoknak mind a térbeli szerkezete, mind pedig a müködése befolyásolhatja az áruk szállítási volumenét.

A multinacionális vállalatok több, a fötevékenységükhöz szorosan nem tartozó funkciót kihelyezve sajátos intellektuális holdingokká válnak. E vállalatok megtartják az irányítási, a szabályozási és a marketingfeladatokat, és szinte az egész termelési folyamatukat kihelyezik. Ennek következtében a nagyvállalatok hálózatszerủ alakzatba szerveződnek. A kihelyezés következménye a vertikális dezintegráció. Azzal, hogy a cégek leépítik a termeléshez szorosan nem kapcsolódó tevékenységeket, laposabbá teszik a szervezeti struktúrát (flattering the organization chart). A vállalat tevékenysége így a térben jobban szétterül, $\mathrm{s}$ ezzel a vállalat a lehetỏ legkevesebb költség mellett növekedhet (Tóth 2001). A költségcsökkenés okai egyrészt a gazdasági racionalizációhoz kötődnek, másrészt pedig a piachoz való közelség, illetve a piaci igényekhez való alkalmazkodás lecsökkenti az áruszállítás volumenét és távolságát.

A vállalkozások mủködésével kapcsolatos folyamatokat megoszthatjuk a beszerzés, a termelés és az elosztás folyamataira.

\section{Beszerzés}

Bizonyos stratégiák nyilvánvalóan az áruszállítás mértékének növekedéséhez vezetnek, ilyen például a „global sourcing”, mely a területi beszerzési hálózat növekedéséhez vezet, vagy a just-in-time elvü beszállítás, mely lecsökkenti a szállítási gyakoriságot és az egy szállitásra jutó árumennyiséget. Az elhalasztott szállítás az 
áru pontos mennyiségének jobb kiszámítását teszi lehetővé, s így lecsökkennek a nem hatékony járatok.

Emellett kiemelhetök a vállalatnak a beszállitóival kialakított kapcsolatrendszerét befolyásoló trendek. A korábbi gyakorlat az volt, hogy a vállalat egyes alkatrészek gyártását kihelyezte beszállítóihoz. A fejlődés viszont a beszállítók számának csökkenése (single sourcing) irányába hat. A vállalatok keretszerzödéseket készítenek a beszállítóikkal, elvárják tőlük az állandó ellenörzést, a minőségtanúsítást és az auditálást. A fejlődés következỏ fázisa az, amikor a külső szállítók már szerelt egységeket, meghatározott gépegységeket szállítanak be (modular sourcing) a megrendelönek. Az outsourcing legmagasabb foka, amikor a vevő és a beszállító között a partnerkapcsolat olyan szoros, hogy a vevö már a fejlesztésekbe, illetve a koncepcióalkotásba is bevonja szállítóit; elvárva tölük, hogy saját fejlesztésük elősegítse a vevő fejlesztéseit (forward sourcing).

Mind a három, említett folyamat kevesebb térbeli interakciót eredményez azzal, hogy igyekszik csökkenteni a beszállítók számát, $s$ így az áruszállítás volumene is lecsökken. A szállitásra gyakorolt hatás abban az esetben nagyobb, ha a beszállítók a vevőtől nagy távolságra helyezkednek el.

\section{Termelés}

A legtöbb tanulmány azt mutatja, hogy a házon belüli termelés lecsökkentése általánosságban az áruszállítás növekedéséhez vezet. Bizonyos esetekben viszont ennek az ellenkezöje is megfigyelhető.

A házon belüli termelés lecsökkenése mellett az ellátási lánc átszervezésével megnőhet a beszállítások száma. A beszállítók váltakozva szállítják a kívánt részegységeket, jóval nagyobb gyakorisággal, mint az eddigi belső áruáramlások, de kisebb tételben, így az áruszállítás volumene megnő. Amennyiben viszont megindul e beszállítók koncentrációja és/vagy közös fellépése annak érdekében, hogy a beszállításuk összehangolt legyen, akkor a szállítás mértéke lecsökken. Másrészt megjelenik napjainkban a logisztikai feladatok szakcégekhez való kihelyezése is. Ez szintén csökkenti a szállítás mértékét, mivel a kapacitáskihasználtság így jóval megfelelöbb.

\section{Elosztás}

Egyre több speciális szállítási cég gyüjti össze a rendeléseket, s szállítja az árut közvetlenül a vásárlókhoz, csökkentve a szállítást. Az elosztási rendszerek további térbeli bővülése, mely felcseréli a nemzeti logisztikai koncepciókat (pl. Eurologistics concept), az általános áruszállítás méttékének további csökkenéséhez vezet. Azt is meg kell viszont jegyezni, hogy e stratégia egyes térségekben (kulcsfontosságú tranzitterületek) a jármüforgalom növekedéséhez vezethet (ThiersteinSchnell 2002). 
Az áruszállítás mértéke tehát szabályozható, illetve logisztikai eszközökkel csökkenthetö, ezek megvalósítása viszont csak a közlekedési infrastruktúra magas fejlettségi fokán képzelhető el, melynek szerves része az autópálya-hálózat.

\section{Befejezés}

A városok közelében megépített, illetve az azokat elkerülö autópályák nagyban kihatnak a város területi folyamataira, hosszú távon módosítják annak szerkezetét. Fontos, hogy e tekintetben a folyamatok rendezett keretek között játszódjanak le, így megelőzhetjük az esetleges káros hatásokat, és egészséges, élhető városszerkezetet érhetünk el.

\section{Irodalom}

Alonso (1964) Location and Land Use. Harvard University Press, Chambridge.

Berion, P. (2000) Modéles et processus de structuration territoriale: quelles contributions des grandes infrastructures de transport? XXXVI ${ }^{\mathrm{E}}$ COLLOQUE DE L' ASSOCIATION DE SCIENCE REGIONALE DE LANGUE FRANCAISE, Crans-Montana (Suisse), 6-9 septembre 2000.

Boarnet, M.G.-Haughwout, A.F. (2000) Do highways matter? Evidence and policy implications of highways influence on metropolitan development. - A disussion paper prepared for The Brooking Institution Center on Urban and Metropolitan Policy.

Dimitrovska, A.K. (2002) Planning in Flux: Changes in the spatial structure of the Central and Eastern European cities: The case study of Ljubljana. - Informationen in Raumentwicklung. 11-12. 693-701. o.

Erdősi F. (2000) A kommunikáció szerepe a terület- és településfejlödésben. VÁTI, Budapest.

Fujita, M. (1989) Urban Economics. New York.

Garreau, J. (1991) Edge City: Life on the New Frontier. Doubleday, New York.

Hartshorn, T.A. (2003) From edge to egdeless city: The transformation of Metropolitan Atlanta. $39^{\text {th }}$ IsoCaRP Congress.

Haughwout, A. (1999) Regional Fiscal Cooperation in Metropolitan Areas: An Exploration, - Journal of Policy Analysis and Management. 4. 579-600.o.

Kószegfalvi Gy. (1997) Telepuilésrendszerünk fejlődésének tendenciải. - Tér és Társadalom. 4. 118-130. o,

Litman, T. (2003) Evaluating transportation land use impacts. Victoria Transport Policy Institute.

Nijkamp, P. (1986) Infrastructure and Regional Development: A Multidimensional Policy Analysis. Empirical Economics. 1.1-21. o.

Pálfalvi J. (szerk.) (2000) Közúti árufuvarozás és személyszállítás az Európai Unióban. Magyar Kereskedelmi és Iparkamara, Budapest.

Raphann, T.J.-Isserman, A.M. (1994) New Highways as Economic Development Tools: An Evaluation Using Quasi-Experimental Matching Methods. - Regional Science and Urban Economics, 6. 723-751.0.

Rodrigue, J-P. (1998) Transport Geography Web Site. Bishop's University, Department of Geography, Hempstead, New York.

Rodrigue, J-P. (2003) Freight, Gateways and Mega-Urban Regions: The Logistical Integration of the BostWash Corridor. Prepared for Tijdschrift voor Sociale en Economische Geografie, Hofstra University, Hempstead, New York.

Stutz, F.P.-De Souza, A.R. (1998) Trade and development. Prentice Hall, Upper Saddle River.

Sykkora, L. (1999) Changes in the internal spatial structure of post-communist Prague. - GeoJournal. 1. 79-89. 0.

Thierstein, A.-Schnell, K-D. (2002) Corporate strategies, freight transport and regional development. DISP. 1. 69-78. o.

Tóth G. (2000) A logisztikai szemlélet megjelenése a Záhonyi Vállalkozási Övezetben. - Területi Statisztika. 2. 163-181. o.

Tóth G. (2001) A vállalati logisztika hatása a területi folyamatokra a RÁBA Holding példáján. - Területi Statisztika. 3. 230-245. o.

Wee, B. van (2002) Land use and transport: research and policy challenges. - Journal of Transport Geography. 10. 259-271, o.

Webster, F.V.-Bly, P.H.-Paulley, N.J. (1988) Urban land-use and transport interaction. ISGLUTI. Avebury, Aldershot. 


\section{THE HIGHWAYS AND URBAN DEVELOPMENT}

\section{GEZA TOTH}

Spatial structure of a part of cities in the USA is determined by highways. Usually, the impact of motorways only modified the spatial structure of cities in Europe. Another important role of motorways can be observed in respect of suburbanisation. A relatively new phenomenon is the emergence of edge cities. Overgrowth of suburbanisation has several harmful impacts which many think are in connection with motorways. However, to counterbalance their impacts is a very important task. Our paper is a short review of these issues. 